\title{
Food waste management — reducing and managing food waste in hospitality
}

\begin{abstract}
Natasa Kilibarda ${ }^{1}$, Filip Djokovic ${ }^{1}$, Radmila Suzic ${ }^{1}$
A b s tr a c t: Food wastage occurs along the entire food chain, from field to table. As much as it is an ethical issue on one hand, it also leads to economic losses and has negative impacts on the environment. Food wastage is, therefore, a significant problem for modern society and the first step in solving it is to identify and understand the reasons for its emergence in each part of the food chain and specific sectors - in this case, the hospitality sector. In order to create practices and recommendations aimed primarily at preventing food wastage, food waste categorization and quantification is essential. This is not that simple, especially in the hospitality sector, given the uneven production of food, and the specific and diverse ways of running a business in this sector. What is certain is that food waste management should be an integral part of management in the hospitality sector, primarily because an effective food safety management system is the starting point for implementing most of the practices that lead to both safe final product and reduction of food waste.
\end{abstract}

Keywords: food wastage, sustainability, food service, measurement, prevention.

\section{Introduction}

The global challenges the world of today faces are population growth, climate change and land use pressure (Philippidis et al., 2019). According to the United Nations Food and Agriculture Organization (FAO), the amount of food discarded daily around the world is one-third of the total food produced for human consumption, which is approximately 1.3 billion tonnes of food per year (Gustavsson et al., 2011). In monetary terms, this is equivalent to US\$ 750 billion. This information bears even greater significance if the fact that in 2018 there were more than 820 million hungry people in the world is taken into account (FAO, IFAD, UNICEF, WFP and WHO, 2019). However, food wastage is not only a complex ethical issue for individuals, as was believed until recently, but it is also an environmental problem which has a negative impact on the global economy. It has been confirmed that food wastage leads to increased emissions of harmful gases, and to water and soil wastage, subsequently impairing biodiversity (FAO, 2013a; FAO, 2014; Betz et al., 2015; Wang et al., 2017). For example, intensive agriculture, without the possibility of field restoration, decreases soil fertility, which in turn leads to more frequent use of artificial fertilizers, increasing the level of environmental pollution and resulting in the loss of arable land. In 2007, about 1.4 billion hectares of land (corresponding in size to Canada and India together) were used to produce food on a global level. Since one third of the food produced is wasted, one third of the total arable land is unnecessarily exposed to exploitation by intensive agriculture, which undeniably, leads to soil degradation. Food wastage also affects climate change, since none of the stages of food production, from fertilizer production to transport of produced food, can occur without the use of fossil fuels (oil). Furthermore, when discarded into landfill, food decomposes under anaerobic conditions, followed by the emission of the greenhouse gas, methane. In 2007, the global carbon footprint of food wastage was estimated at 3.3 Gtonnes of $\mathrm{CO}_{2} \mathrm{eq}$, which is twice the amount of greenhouse gas emissions of all US road transportation in 2010 (FAO, 2013b). This means food wastage accounted for $8 \%$ of global greenhouse gas emissions that year (FAO, 2013b).

Food wastage is also one of the factors with a strong impact on biodiversity, which indirectly increases the need for new farmland. Due to the need for more food (despite food wastage), there is increasing deforestation $(74 \%$ of total global annual deforestation) and formation of farmland in wilderness areas, which leads to extinction of wildlife. Additionally, to offset the need for

${ }^{1}$ Singidunum University, 32 Danijelova st., 11010 Belgrade, Republic of Serbia.

Corresponding author: Kilibarda Natasa, nkilibarda@singidunum.ac.rs 
agriculturally-produced food, water resources are being depleted through uncontrolled fishing (FAO, 2013b).

Given the multiple negative impacts of food wastage on global development, it is clear this impact can only be reduced by implementing strategies to limit the amount of food waste generated. First of all, this requires the development of awareness among individuals, the application of best practices and responsible behaviour, and the involvement of the scientific community and competent authorities (Janjić et al., 2019). Also, food business entities must develop an awareness of the amount of food wastage they produce and its impact at the global level. A concerted effort by all involved would contribute to the development of a society that meets human needs by utilizing the available resources, without further compromising natural systems and the environment. This is the only way to ensure the long-term existence of human society and its environment (Tekin and Ilyasov, 2017).

Food wastage exists along the entire food chain, starting with agricultural production, post-harvest treatment and storage, and it continues through food production, distribution, consumption and end-of-life (FAO, 2013b), i.e. it covers everything from field to table, including the hospitality sector. However, in order to understand the scope of this problem, the terms food loss and food waste must be distinguished. According to $F A O$, (2013a): "Food loss refers to the decrease in mass (dry matter quantity) or nutritional value (quality) of food that was originally intended for human consumption", while "food waste refers to food deemed appropriate for human consumption being discarded, regardless of whether it is kept beyond its expiry date, or left to spoil". That is why, when it comes to food waste in general, regardless of its occurrence and its place in the food chain, the term food wastage is used. "Food wastage refers to any food lost by deterioration or by being discarded". Thus, the term "wastage" encompasses both food loss and food waste (FAO, 2013a). Food loss occurs mostly during the earlier phases of the food chain, mainly in developing countries. This is due to the limited post-harvest infrastructure and underdeveloped technologies (Parfitt et al., 2010; Dorward, 2012; Kummu et al., 2012; Wang et al., 2017). In contrast, food waste occurs mainly in developed countries and in the consumption phase, so primarily is the responsibility of consumers, reflecting their behaviour and attitude towards food (Stenmarck et al., 2016; Reynolds et al., 2019). For instance, in sub-Saharan Africa, more than $90 \%$ of food waste occurs in the pre-consumption phase (Gustavsson et al., 2011), while, on the other hand, in Europe, up to 53\% of food waste is from households at the consumption phase (Stenmarck et al., 2016). The household sector contributes most to the generation of food waste (47 million tonnes \pm 4 million tonnes), followed by the food processing sector (17 million tonnes \pm 13 million tonnes). These two sectors are said to be responsible for $72 \%$ of EU food waste. The remaining $28 \%$ of food waste is comprised of 11 million tonnes $(12 \%)$ of waste that comes from food service, 9 million tonnes $(10 \%)$ from primary production, and 5 million tonnes $(5 \%)$ from wholesale and retail (Stenmarck et al., 2016). The food service, which includes hospitality sector, is third in terms of the amount of food waste produced, and so is a significant contributor to this problem that can and must be influenced.

\section{Food Waste Generation in the Hospitality Sector}

Due to globalization, there has been a worldwide increase in living standards and an increase in per capita earnings, leading to growth in the hospitality sector (Pirani and Arafat, 2014; Kaur, 2017; World Tourism Organization, 2019). Food preparation businesses in the hospitality sector include hotels, restaurants, cafes, bars, sandwich shops and similar businesses, providing takeaway food and/or sit-down meals on the premises (Pirani and Arafat, 2014). With the development of the hospitality sector, the number of food preparation businesses has also increased, proportionately leading to a greater amount of food waste generated (Ball and Taleb, 2011; Pirani and Arafat, 2016; Filimonau and De Coteau, 2019). The $21^{\text {st }}$ century, on the other hand, has led to changes in consumers' life styles and habits (Sarcevic et al., 2018). Due to the lack of time to prepare meals at home, people increasingly resolve to purchase takeaway meals or dine outside the home in restaurants (von Massow and McAdams, 2015; Kilibarda, 2019a).

The only way to solve the problem of food waste, which has become a problem of modern society, is to understand and identify the reasons for its occurrence in every part of the food chain, and identify the specific sectors which contribute to its generation. For this reason, numerous studies have been conducted with the aim of categorizing and quantifying food waste.

Food waste generated in the hospitality sector can be divided into two categories, depending 
on whether it is generated before or after the food is consumed. Pre-consumer food waste occurs during the procurement and storage of purchased raw materials (storage/purchase waste), then during the food preparation (preparation waste), and food exposure (as a result of overproduction) (Baldwin, 2015; Betz et al. 2015; Costello et al., 2016; Pirani and Arafat, 2016, Kilibarda, 2019b). Post-consumer waste refers to leftovers on the plate itself. Waste generated at this stage is also called plate food waste (Costello et al., 2016) and is defined as food purchased by a consumer and subsequently not eaten (Costello et al., 2016). Overproduction waste could also be seen as post-consumer waste since it refers to food that, although not sold to the consumer, is prepared with this intention (Costello et al. 2016). Food waste can also be classified depending on whether it is edible or inedible, and whether it can be prevented or not (WRAP, 2009; Parfitt et al., 2010). Edible food waste refers to the waste resulting from excessive amounts of prepared food, spoiled food, improper processing of food, expired food, or food leftovers. This avoidable food waste results from preparing or serving food in larger quantities than necessary; it can be the result of overcooking or random mistakes (i.e. in recipes) during food preparation, which can put at risk the required quality that is expected or demanded (Betz et al., 2015; Papargyropoulou et al., 2016; Kilibarda, 2019b). The largest amount of edible, and therefore, avoidable food waste is buffet leftovers (Betz et al., 2015; Papargyropoulou et al., 2016). In the hospitality sector, avoidable food waste accounts for $56 \%$ or more of the total food waste (Papargyropoulou et al., 2016). On the other hand, inedible food waste refers to food residues such as eggshells, inedible parts of fruits and vegetables, animal bones and seafood shells, all resulting from the mechanical processing and preparation of food (Betz et al., 2015; Papargyropoulou et al., 2016). This waste type is unavoidable (Betz et al., 2015; Papargyropoulou et al., 2016). Plate food waste is most often a mix of inedible food chunks and edible surplus (Papargyropoulou et al., 2016).

In the hospitality sector, the amount of food discarded by restaurants depends on the type of service or the type of restaurant (Kilibarda, 2019b). The largest amount of superfluous food is derived from buffet-style restaurants rather than à la carte restaurants (Papargyropoulou et al., 2016; Pirani and Arafat, 2016). Post-consumer (plate) food waste is usually composed of side dishes (accompaniments) like salads and starchy foods such as potato, rice, pasta and bread, while main dish leftovers are uncommon. In the process of food preparation, fruits and vegetables are the most commonly wasted foods (Silvennoinen et al., 2012; Betz et al., 2015; Papargyropoulou et al., 2016; Pirani and Arafat, 2016).

The reasons for food waste generation differ depending on the phase in which the waste is generated. In the phase of procurement and storage of basic food preparation ingredients, the most common reason for waste generation is non-compliance with good hygiene and good manufacturing practices (Kilibarda, 2019b). These defined procedures ensure safe handling of food and the food's safety and convenience, but non-compliance with temperature regimes or non-application of the first in-first out principle can generate food waste (Engstrom and Carlsson-Kanyama, 2004). Lump sum ordering can lead to poorly planned procurement or bulk procurement of food, so accumulated food, if not used up, expires and must be discarded (Baldwin, 2015). During the food preparation phase, unavoidable inedible food waste is usually generated through mechanical processing. The amount of this food waste can be larger than acceptable, especially if such processing is carried out with inadequate equipment or by unskilled personnel (Baldwin, 2015; Papargyropoulou et al., 2016). Employees' misjudgement of the expected number of customers often leads to overproduction in the food preparation phase. Therefore, cooperation and exchange of information about the number and type of customers among all hospitality sectors is very important. Lack of communication and poor coordination among sectors involved in purchase, preparation (kitchen) and serving (wait staff) also lead to generation of excessive waste (Papargyropoulou et al., 2016; Priefer et al., 2016; Kilibarda, 2019b). In the serving phase, the largest amount of discarded food occurs after food has been used in buffet style service (Silvennoinen et al., 2012; Betz et al., 2015; Papargyropoulou et al., 2016; Pirani and Arafat, 2016). This is because the rules regarding the maximum duration and temperature regime of food exposure at buffet tables are not adequately followed (Papargyropoulou et al., 2016). Also, the amount of food offered is plentiful and the price is fixed (Priefer et al., 2016), factors that stimulate consumers to overfill their plates with more food than they can eat. However, management would rather waste food than lose customers; that is, by displaying excessive quantities of food they aim to please customers and exceed their expectations (Papargyropoulou et al., 2016). All of this leads to post-consumer food 
waste, which is most often caused by oversize portions (Pirani and Arafat, 2014; Priefer et al., 2016; Reynolds et al., 2019). Oversize portions require larger quantities of ingredients and are mostly the result of non-compliance with standard defined portion sizes. This plate waste also occurs when customer judges an ordered dish does not have the expected and/or required quality (Baldwin, 2015). Finally, the amount of waste generated in the hospitality sector also depends on the season, the number of customers, days of the week, the location where the waste is generated, etc. (Merchant and Cloy, 2017).

\section{Food Waste Management in Hospitality}

The concept of sustainable development in contemporary business conditions has become a framework for strategic decision-making in hospitality (Djokovic, 2018). It rests on three pillars of sustainability: economic, environmental and social. The economic pillar stems from the raison d'etre of every business, to make a profit. The environmental pillar is based on conservation of the environment and all the resources available in the hospitality sector's location. The social pillar refers to all the factors that affect the quality of life and well-being of the population. All pillars of the hospitality sector's sustainable development are interdependent, since business success should be derived from the environmental protection of a particular destination (region) and improvement of the quality of life of people directly (employed in the hospitality sector) and indirectly (employed in other segments of the tourist industry, tourists and other consumers) related to this sector. At the same time, life today is characterized by the fact that the modern consumer's demands on the services offered by the hospitality sector are becoming more sophisticated and complex. According to the UNWTO (2019), tourists' motives are directly correlated with the principles of sustainable development. The hospitality sector, in accordance with these requirements, has started to adapt to the concept of sustainable development. In order for this concept to have practical implications, it is essential the strategic orientation of the hospitality sector towards environmental protection is reduced to operational management mechanisms. The state should, by a legal framework, encourage hospitality sector entities to use their businesses to improve an environmentally friendly ambience. The key areas of hospitality management, taking into the account the concept of sustainable development, include energy efficiency, the use of renewable energy sources and waste management. Energy efficiency and the use of renewable energy sources are a priority in hospitality management due to the lowering of operating costs and reducing local pollution.

As has been pointed out, global food production leads to losses that are associated with consumers and food consumption, especially in developed countries (Racz et al., 2018). Therefore, the hospitality sector can play an important role in raising awareness of the value of food in order to globally reduce food wastage. However, waste management has become an unresolved issue for most hospitality sector entities, including those in Serbia. For example, hotels are large waste producers due to their intensive business activities. In practice, there is a daily problem of waste disposal and storage, especially in tourist destinations with a distinctive seasonal character. The most common wastes the hospitality sector produces are food and packaging (cardboard, plastic and glass packaging containing food, beverages, cleaning and cosmetic products) wastes. For hospitality sector management, the demands are great, as consumers expect satisfaction with both service and food. Simultaneously, the government's food safety standards must be fulfilled. Then, management expects increasing profits. Finally, there is growing concern for environmental conservation (Rodgers, 2005), creating yet another challenge food waste management - for hospitality management.

\section{Food Waste from Prevention to Disposal}

It is important for management in the hospitality sector to identify and define the reasons for the occurrence of food waste in order to create and provide practices and procedures that will prevent or reduce this waste.

The Community Strategy for Waste Management (European Parliament Council, 1989) defines the food waste hierarchy. Its basic objective is sustainable food management, the first and most desirable step of which is prevention (Papargyropoulou et al., 2014). The desirability of the other proposed steps towards achieving the sustainable objectives decreases in the order specified in the guidance. The following proposed steps include: reusing, diverting unused food for human or animal consumption, and recycling food waste via composting or renewable energy generation. However, the last step, and the least desirable one, is disposal of food waste in landfills (Papargyropoulou et al., 2014; Baldwin, 2015; HOTREC, 2017). 
As the prevention or reduction of food waste is a priority activity in the process of waste reduction, specific recommendations should be implemented in the hospitality sector. They also integrate the principles of sustainable development in managing food waste. With the aim of responsible behaviour, the following stages should be included:

- procurement of groceries - base procurement procedures on needs, and select suppliers that can meet those needs;

- inventory management - meet appropriate best conditions for storing groceries, monitor the dynamics of grocery consumption, and keep special, dedicated records on the types and amounts of food waste generated (Silvennoinen et al., 2012; Baldwin, 2015; Priefer et al., 2016);

- portion control - use groceries according to food norms and efficiently use food residues from previous meals; train kitchen staff appropriately to reduce food waste. Reduce portion sizes, especially for those types of foods known to make up the largest part of plate food waste (Engstrom and Carlsson-Kanyama, 2004; Betz et al., 2015; Papargyropoulou et al., 2016).

- serving meals to guests - focus on the quality of the service and the competence of the wait staff. For buffet presentation, reduce the amount of displayed food, and take into account the time/temperature of warm meal exposure (Engstrom and Carlsson-Kanyama; Betz et al., 2015; Priefer et al., 2016);

- raise consumers' awareness of the negative effects of food waste (Engstrom and Carlsson-Kanyama, 2004; Betz et al., 2015; Pirani and Arafat, 2016; Priefer et al., 2016; HOTREC, 2017). Encourage consumers to take their own leftovers home for later consumption in specially prepared packages (Zuraikat et al., 2018);

- manage leftover food - establish procedures to ensure rational management of leftovers to minimize waste generation (give leftovers to animals, prepare and sort leftovers for employees, donate food to soup kitchens and similar institutions);

- disposal - ensure any final food waste is used in aerobic composting and establish procedures for quarterly analysis to improve waste disposal (Awasthi et al., 2018).

An effective food safety management system must be the basis for implementing the large number of stages mentioned. ISO 22000 is an international standard for food safety management systems that defines the requirements of a food safety management system. This standard is based on the principles of the hazard analysis and critical control point (HACCP) system and the requirements of the ISO 9001 standard. This standard combines the recognized key elements of food safety such as interactive communication, system management, process control, HACCP principles and prerequisite programs (Kilibarda, 2019a). In the USA, 55-60\% of all foodborne outbreaks of disease were from restaurants (Thaivalappil et al., 2018). In the EU Member States, the hospitality sector ranks as second in terms of foodborne disease, as confirmed by EFSA data (2018). In this regard, implementing ISO 22000 standard, with its primary objective of producing safe food, has a two-fold and very important benefit, since food waste is also greatly reduced when the requirements of this standard are met. Also, this standard deals with predictions and analysis of a large number of external factors and hazards that not only can endanger food safety, but can also adversely affect the production process and finances of companies and employees. Bearing in mind the need to integrate the concept of sustainable development in the hospitality sector, we emphasize the ISO 14000 (environmental management system; EMS) standards related to environmental protection. ISO 14000 is a risk management standard, dedicated to controlling the risks of environmental pollution. The EMS establishes mechanisms that, over time, reduce these risks and the number of incidents, and enhance the business's reliability in meeting its legal and other environmental requirements. This is one of the preconditions of any business run in accordance with the sustainable development goals.

In the hospitality sector worldwide, there are currently over 100 voluntary eco-labels. These eco-labels refer to various aspects of environmental management activities, including food waste management. On a global scale, the Green Key is the most recognizable and widespread eco-label to be awarded in the hospitality sector. Green Key is supported by the World Tourism Organization and the United Nations Environment Program (UNEP). The problem with eco-labels is that they are voluntary and very expensive for individual entities. In Serbia, only four hotels currently hold a Green Key Certificate. The Certified Green Restaurant is a restaurant-only eco-label granted exclusively in the USA and Canada for the time being, although there are some indications that this type of certification will be extended to other countries (Pirani and Arafart, 2014). 


\section{Food Operators in Hospitality and Their Attitude Towards Food Waste Management}

In addition to achieving the UN's sustainable development goals, implementing more effective practices in food logistics, storage and preparation, and hospitality businesses can minimize the costs of food waste management (Papargyropoulou et al., 2014). According to WRAP (2013), if currently generated waste were reduced by $5 \%$, more than $£ 250$ million would be saved in the hospitality sector

Creating a hotel management model that includes food waste management depends largely on whether the hotel belongs to a chain or is independent. If a hotel belongs to a corporate hotel chain or is a part of consortium, the establishment of a food waste management system is integrated through the business standards of that chain. The construction and furnishing of the hotel provide the infrastructure for the implementation of standards, including the training of employees in the food and beverage sector. Independent hotels are able to create and enforce their own standards, negating the ability to create a single system that will oblige hotels to have a comprehensive food management system. Therefore, the biggest challenges are related to independent hotels, which, due to material and human resources, can have limited capacity to initiate and implement food waste management standards (Djokovic, 2018).

However, in the hospitality sector, managers of small hotels or food business entities are often not interested in adopting and implementing eco-friendly practices, since they believe the amount of food waste they produce is insignificant. This is the biggest problem regarding this waste's negative environmental impact, since all food waste from these small entities is generally directed to landfills, which is the least acceptable solution. This attitude could be due to the lack of official guidance on the importance of reducing the food waste they generate, meaning they do not think about the issue. Also, they lack the support of competent institutions and government bodies, and therefore, they do not want to spend either their time or their money, believing effective food waste management will only cause financial losses, and will not save material resources (Pirani and Arafart, 2014).

In a hotel survey conducted by Pirani and Arafart (2014) a significant percentage of hotel kitchens (44\%) were equipped with signs encouraging staff to minimize food waste. On the other hand, it is very interesting that signs of similar content, directing guests towards responsible behaviour and awareness of food waste, cannot be found in hotel restaurants. In fact, only $7 \%$ of the surveyed hotels had conducted a campaign aimed at raising awareness among guests to act more responsibly regarding food waste generation. Also, $67 \%$ of hotels compost or plan to compost their food surpluses, while $47 \%$ of hotels donate both surplus and unused food. The most common reason for those who do not compost is the belief they do not generate enough waste, while those who do not donate admit that they were not aware of the existence of such charity programs, or they see obstacles to food donation in the food safety legislation. Food business entities, in this case, food operators in the hospitality sector, are responsible for food safety (according to General Food Law Regulation (EC) 178/2002). However, in the case of food donations, they do not wish to bear responsibility for the safety of food post-donation, which is beyond their control. For this reason, food operators actually feel forced to discard food in order to avoid being held accountable for its safety in the case of donations (Priefer et al., 2016). A more flexible approach to food safety liability would reduce the amount of irreversibly discarded food in these situations. Shifting responsibilities wholly or partially from the management of food operators in the hospitality sector would help redirect surplus food to those who need it most.

\section{Modern Technology and Food Waste Management}

The expansion of advanced technologies has enabled the development of various smartphone applications that facilitate quantification and categorization of food waste in hospitality sector kitchens. For example, there is a "Wise Up on Waste" application developed by Unilever Food Solutions (2017) that helps chefs measure, monitor and manage food waste in their kitchens. Research shows that adopting such technological innovations can significantly reduce food waste (Gould, 2016). From a consumer perspective, a smartphone application ("Too Good To Go") has been developed to help consumers buy prepared meals from restaurants at significantly lower prices at the end of the day, thus reducing waste and waste disposal costs, and increasing sales at the same time. According to their data, Too Good To Go is currently used in 14 European countries, numbering more than 26 million sold meals which is equivalent to $66,000,000 \mathrm{~kg}$ of prevented $\mathrm{CO}_{2}$ emissions - about the same as taking $>11,000$ cars off the road for a year (Filimonau and De Coteau, 2019). 
However, in Serbia, the implementation of such applications has not proved encouraging. The reason is that a large part of the population would, in fact, tend to exclusively buy meals from restaurants at the end of the business day. This would have a significant impact on restaurant earnings, since the number of visits would significantly decrease during the day (personal communication).

\section{Conclusion}

It is clear that food wastage has an impact on global sustainable development, and the facts themselves support the extent to which the negative impact on the environment would be decreased if the amount of food waste on a global level were reduced. Due to the numerous operational activities in hospitality, it is not possible to completely eliminate food waste. However, new/revised procedures and regulations in the hospitality sector (and other sectors that produce food waste) will reduce the quantity of food waste (Kasavan et al., 2017). Food waste management should be an integral part of hospitality management, especially since an effective food safety management system is the basis for implementing most of the practices that have led to the reduction of food waste in hospitality. This accomplishes an even more important food safety goal, which is to ensure the production of a safe product and the health of consumers. Positive food waste management practices in the hotel industry can have a stimulating effect on other hotels, hotel chains and associations. Sharing experiences increases the opportunities for involvement of stakeholders in food waste production, which can lead to greater organizational culture of businesses and environmental awareness of individuals. However, to successfully manage food waste, in addition to motivating management interest, the food waste generated by the hospitality sector must be initially categorized and quantified. There are numerous challenges for managers, as food waste management needs to be integrated into other business areas that include human resource training, enterprise software and technology.

\title{
Upravljanje otpadom od hrane - smanjenje i prevencija nastanka otpada od hrane u ugostiteljstvu
}

\author{
Nataša Kilibarda, Filip Đoković, Radmila Suzić \\ A p s tr a kt: Otpad od hrane nastaje duž celog lanca hrane, od njive do trpeze. Bacanje hrane predstavlja etičko pitanje, zatim \\ dovodi do ekonomskih gubitaka, ali i utiče negativno na životnu sredinu. Otpad od hrane je iz tog razloga značajan problem savreme- \\ nog društva i prvi korak u njegovom rešavanju jeste identifikacija i razumevanje razloga njegovog nastanka u svakom delu lanca hrane \\ i specifičnim sektorima kao što je ugostiteljstvo. Kako bi se kreirale prakse i preporuke koje bi za cilj imale, pre svega, sprečavanje na- \\ stanka otpada od hrane, neophodno je kategorisati i kvantifikovati otpad od hrane. U ugostiteljstvu to i nije tako jednostavan zadatak, \\ uzimajući u obzir neujednačenu proizvodnju hrane i specifičan i raznolik način obavljanja delatnosti subjekata koji posluju hranom u \\ ovom sektoru. Ono što je sigurno jeste da upravljanje otpadom od hrane treba da bude sasatvni deo menadžmenta u ugostiteljstvu, pre \\ svega zbog toga, što efektivni sistem upravljanja bezbednošću hrane predstavlja polaznu osnovu za implementaciju većine praksi koje \\ dovode, kako do bezbednog finalnog proizvoda, tako i do smanjenja otpada u ugostiteljstvu.
}

Ključne reči: otpad od hrane, održivost, ugostiteljstvo, kvantifikacija, prevencija.

Disclosure statement: No potential conflict of interest was reported by the authors. 


\section{References}

Awasthi, M. K., Wang, Q., Wang, M., Chen, H., Ren, X. \& Zhang, Z. (2018). In-vessel co-composting of food waste employing enriched bacterial consortium. Food Technology \& Biotechnology, 56(1), 83-89.

Baldwin, C. J. (2015). The 10 Principles of Food Industry Sustainability. Wiley-Blackwell, UK.

Ball, S. \& Taleb, M, A. (2011). Benchmarking waste disposal in the Egyptian hotel industry. Tourism and hospitality research,11, 1-18.

Betz, A., Buchli, J., Göbel, C. \& Müller, C. (2015). Food waste in the Swiss food service industry - Magnitude and potential for reduction. Waste management, 35, 218-226. doi: 10.1016/j.wasman.2014.09.015

Costello, C., Birisci, E. \& McGarvey, R, G. (2016). Food waste in campus dining operations: Inventory of preand post-consumer mass by food category, and estimation of embodied greenhouse gas emissions. Renewable agriculture and food systems, 31, 191-201. doi: 10.1017/ S1742170515000071.

Djokovic, F. (2018). Odlučivanje u hotelijerstvu [Decision making in hospitality industry]. Singidunum University, Valjevo, Serbia.

EFSA (2018). The European Union summary report on trends and sources of zoonoses, zoonotic agents and food-borne outbreaks in 2017. EFSA Journal 16(12), 5500. doi: 10.2903/j.efsa.2018.5500

Engstrom, R. \& Carlsson-Kanyama, A. (2004). Food losses in food service institutions Examples from Sweden. Food Policy, 29(3) 203-213. doi: 10.1016/ S0306-9192(04)00020-X

FAO. (2013a). Food wastage footprint: impacts on natural resources: summary report. FAO, Rome

FAO. (2013b). Toolkit: reducing the food wastage footprint. FAO, Rome.

FAO. (2014). Food wastage footprint full-cost accounting: final report. Food Wastage Footprint. FAO, Rome.

FAO, IFAD, UNICEF, WFP and WHO. (2019). The State of Food Security and Nutrition in the World 2019. Safeguarding against economic slowdowns and downturns. FAO, Rome.

Filimonau, V. \& De Coteau, D. A. (2019). Food waste management in hospitality operations: A critical review. Tourism management, 71, 234-245. doi: 10.1016/j.tourman.2018.10.009.

Gould, L. H. Rosenblum. I., Nicholas, D., Phan, Q. \& Jones, T. F. (2013). Contributing factors in restaurant-associated foodborne disease outbreaks, FoodNet sites, 2006 and 2007. Journal of Food Protection, 76, 1824-1828. doi: 10.4315/0362-028X.JFP-13-037

HOTREC (2017). European hospitality industry guidelines to reduce food waste and recommendations to manage food donations. HOTREC Hospitality Europe, Brussels, Belgium.

Janjic, J., Popovic, M., Radosavac, A., Sarcevic, D., Grbic, S., Starcevic, M. \& Baltic, Z. M. (2019). Household food waste in Belgrade - sin and unconcern. The 60th International Meat Industry Conference MEATCON2019, OP Conf. Series: Earth and Environmental Science, 333. doi:10.1088/1755-1315/333/1/012039
Kasavan, S., Fariz Mohamad, A. \& Abdul Halim, S. (2017). Sustainable food waste management in hotels: case study Langkawi Unesco Global Geopark. Journal of the Malaysian Institute of Planners, 15(4), 57-68.

Kaur, I. (2017). Role of hotel management and catering technology institutes in ensuring food safety. In Food safety in the 21st century: public health perspective. Eds P. Dudeja, R. K. Gupta \& A. S. Minhas, 1st edn. Elsevier, Amsterdam, 321-335.

Kilibarda, N. (2019a). Bezbednost hrane [Food safety]. Singidunum University, Belgrade, Serbia.

Kilibarda, N. (2019b). Food Safety and Food Waste in Hospitality. Encyclopedia of the UN Sustainable Development Goals. Zero Hunger, ISBN 978-3-319-69626-3. accepted for publication.

Papargyropoulou, E., Lozano, R. K., Steinberger, J., Wright, N. \& Ujang, Z. (2014). The food waste hierarchy as a framework for the management of food surplus and food waste. Journal of Cleaner Production, 76, 106-115. doi: 10.1016/j.jclepro.2014.04.020

Papargyropoulou, E., Wright, N., Lozano, R., Steinberger, J., Padfield, R. \& Ujang, Z. (2016). Conceptual framework for the study of food waste generation and prevention in the hospitality sector. Waste Management, 49, 326-336. doi: 10.1016/j.wasman.2016.01.017

Parfitt, J., Barthel, M. \& Macnaughton, S. (2010). Food waste within food supply chains: quantification and potential for change to 2050. Philosophical Transactions of The Royal Society B Biological, 365, 3065-308. doi: 10.1098/rstb.2010.0126

Philippidis, G., Sartori, M., Ferrari, E. \& M'Barek R. (2019). Waste not, want not: A bio-economic impact assessment of household food waste reductions in the EU. Resources, conservation, and recycling 146, 514-522. https://doi. org/10.1016/j.resconrec.2019.04.016

Pirani, S. I. \& Arafat, H. A. (2014). Solid waste management in the hospitality industry: A review. Journal of Environmental Management, 146, 320-336. doi: 10.1016/j.jenvman.2014.07.038

Pirani, S. I. \& Arafat, H. A. (2016). Reduction of food waste generation in the hospitality industry. Journal of cleaner production, 132, 129-145. doi: 10.1016/j.jclepro.2015.07.146

Priefer, C., Jörissen, J. \& Bräutigam, K. R. (2016). Food waste prevention in Europe - A cause-driven approach to identify the most relevant leverage points for action. Resources, conservation, and recycling, 109, 155-165. doi: 10.1016/j.resconrec.2016.03.004

Racz, A., Vasiljev Marchesi, V. \& Crnkovic, I. (2018). Economical, environmental and ethical impact of food wastage in hospitality and other global industries. Europski Ćasopis za Bioetiku, 9(1), 25-42.

Reynolds, C., Goucher, L., Quested, T., Bromley, S., Gillick, S., Wells, V.K., Evans, D., Koh, L., Carlsson Kanyama. A., Katzeff, C., Svenfelt, Å. \& Jackson, P. (2019). Review: Consumption-stage food waste reduction interventions What works and how to design better interventions. Food Policy, 83, 7-27. doi: 10.1016/j.foodpol.2019.01.009 
Rodgers, S. (2005). Food safety research underpinning food service systems - a review. Food service technology, 5, 67-76. /doi/abs/10.1111/j.1471-5740.2005.00113.x

Sarcevic, D., Lilic, S. \& Vranic, D. (2018). Redukcija soli u ishrani ljudi - globalna strategija u 21. veku. Meat Technology, 55(2), 162-168.

Silvennoinen, K., Katajajuuri, J. M., Hartikainen, H., Jalkanen, L., Koivupuro, H. K. \& Reinikainen, A. (2012). Food waste volume and composition in the Finnish supply chain: special focus on food service sector. In: Proceedings, Forth International Symposium on Energy from Biomass and Waste, Cini Foundation, Venice, Italy, 12 15 November.

Stenmarck, Å., Jensen, C., Quested, T., Moates, G., Buksti, M., Cseh, B., Juul, S., Parry, A., Politano, A., Redlingshofer, B., Scherhaufer, S., Silvennoinen, K., Soethoudt, H., Zübert, C. \& Östergren, K. (2016). Estimates of European food waste levels. Fusions report, Stockholm.

Tekin, O. A. \& Ilyasov, A. (2017). The food waste in five-star hotels: A study on Turkish guests' attitudes. Journal of Tourism and Gastronomy Studies, 5(3), 13-31.

Thaivalappil, A., Waddell, L., Greig, J., Meldrum, R. \& Young, I. (2018). A systematic review and thematic synthesis of qualitative research studies on factors affecting safe food handling at retail and food service. Food Control, 89, 97-107. doi: 10.1016/j.foodcont.2018.01.028

von Massow, M. \& McAdams, B. (2015). Table Scraps: An Evaluation of Plate Waste in Restaurants. Journal of foodservice business research, 18, 437-453. doi: 10.1080/15378020.2015.1093451

Wang, L., Liu, G., Liu, X., Liu, Y., Gao, J., Zhou, B., Gao, S. \& Cheng, S. (2017). The weight of unfinished plate: A survey based characterization of restaurant food waste in Chinese cities. Waste Manag, 66, 3-12. doi: 10.1016/j. wasman.2017.04.007

World Tourism Organization (2019). International tourism highlights. UNWTO, Madrid. doi: https://doi. org/10.18111/9789284421152

WRAP (2009). Household Food and Drink Waste in the UK. Report prepared by WRAP, Banbury.

WRAP (2013). Overview of Waste in the UK Hospitality and Food Service Sector. Written by: Oakdene Hollins, Responsible Hospitality Partnership and WRAP.

Zuraikat, F. M., Roe, L. S., Smethers, A. D. \& Rolls, B. J. (2018). Doggy bags and downsizing: Packaging uneaten food to go after a meal attenuates the portion size effect in women. Appetite, 129, 162-170. doi: 10.1016/j.appet.2018.07.009 